\title{
The Influence of Phosphate and Other Nutrients on the Development of Vesicular-arbuscular Mycorrhiza in Culture
}

\author{
By BARBARA MOSSE AND J. M. PHILLIPS \\ Rothamsted Experimental Station, Harpenden, Hertfordshire
}

(Accepted for publication I8 August I97I)

\begin{abstract}
SUMMARY
Vesicular-arbuscular mycorrhiza were established in Trifolium parviflorum in culture by inoculation with Endogone spores. In a medium containing $265 \mathrm{mg}$. phosphorus (P)/l., as $\mathrm{CaHPO}_{4}$ and $\mathrm{K}_{2} \mathrm{HPO}_{4}$, infection occurred only when the medium lacked nitrogen $(\mathrm{N})$. In a medium containing only $100 \mathrm{mg}$. $\mathrm{P} / \mathrm{l}$., infection occurred readily in the presence of $0.5 \mathrm{~g}$. $\mathrm{KNO}_{3} / 1$.

Calcium monohydrogen phosphate, Ca phytate, Na phytate, Fe phytate, phytin, lecithin and DNA were adequate sources of phosphate for both plant and fungus. Ca phytate and DNA greatly stimulated fungal growth, and DNA also stimulated spore formation, in the agar medium. With $\mathrm{Na}$ in the medium infections in the root were sparse. Inositol may serve as a carbon source for Endogone.

Mycorrhizal infection occurred with either $\mathrm{FeCl}_{3}$ or $\mathrm{Fe}$-EDTA in the medium; when so little iron was present that plants grew poorly, there was also little mycorrhizal infection.
\end{abstract}

\section{INTRODUCTION}

Typical vesicular-arbuscular (VA) mycorrhiza were established for the first time, in monoxenic culture in clover seedlings in an inorganic salt medium commonly used in studies on nodulation (Jensen, I942); this medium lacked nitrogen (N) and contained $265 \mathrm{mg}$. phosphorus (P) (as $\mathrm{CaHPO}_{4}$ and $\mathrm{K}_{2} \mathrm{HPO}_{4}$ )/l. Germinated, surface-sterilized spores of an Endogone sp. were used as inoculum. Infection occurred only with spores already germinated and when entry into the root was assisted by bacteria, by an extract from a bacterial culture, by EDTA or by pectinase (Mosse, 1962). If $\mathrm{N}$ was added infections occurred only after the host plant had removed this $\mathrm{N}$ from the medium. We have now obtained typical $\mathrm{VA}$ infections in a medium containing $\mathrm{N}$ with surface-sterilized Endogone spores not previously germinated. The two media differ in the source and amount of phosphate, the presence or absence of charcoal, the use of Fe-EDTA instead of $\mathrm{FeCl}_{3}$, and the use of $\mathrm{CaCl}_{2}$ instead of $\mathrm{NaCl}$. This paper examines which of these differences is responsible for the better results in the second medium.

We also tested various other organic $P$ compounds, viz. phytin, sodium phytate, iron phytate, glucose-6-phosphate, lecithin and DNA, and inositol (the carbon framework of the phytates). The results allow some deductions about the physiology of the Endogone sp., which is an obligate symbiont not so far cultured without a host plant.

\section{METHODS}

Test plants. Seeds of Trifolium parviflorum were sterilized in concentrated $\mathrm{H}_{2} \mathrm{SO}_{4}$, chilled and germinated on agar plates (Nutman, 1949). The germinated seeds were placed singly on agar slopes in test tubes kept in a glass house with a day temperature of $20^{\circ}$ and a night 
temperature of $15^{\circ}$. During the winter a $\mathrm{I} 2 \mathrm{~h}$. day was maintained by supplementary fluorescent lighting.

Inoculum. Resting spores of Endogone mosseae (Nicolson \& Gerdemann, 1968) were excized from sporocarps and surface sterilized in $2 \%(\mathrm{w} / \mathrm{v})$ Chloramine T containing $200 \mathrm{mg}$. streptomycin/l. and a trace of detergent (Mosse, 1962). Spores were either transferred by capillary pipettes to watch glasses containing the sterilant and then rinsed in three changes
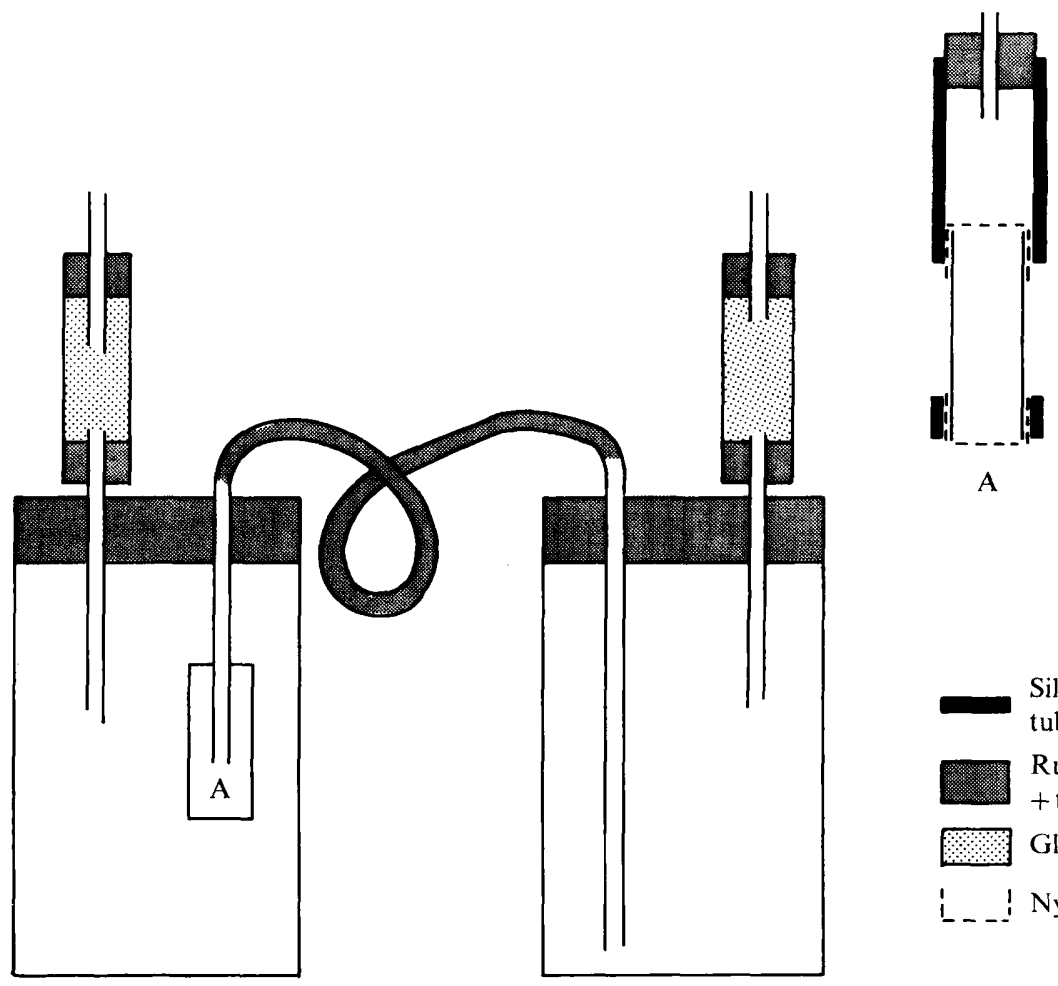

A

Fig. I. Apparatus used for sterilizing Endogone spores.

of water, or they were placed in a small glass tube (A) closed at the ends by nylon gauze held in place by a rubber ring, and connected by flexible tubing to a reservoir containing sterilant or water (Fig. I). Spores were sterilized and rinsed in this container by raising and lowering the reservoir several times. Both methods produced surface-sterilized spores capable of germination. When seedlings had formed some first-order laterals, usually two weeks after sowing, they were inoculated by placing Io to I 5 sterilized spores near the roots growing on the agar surface.

Media. The composition of media tested is given in Table I.

Phytin was extracted from wheat bran as described by Clark (1914). Iron phytate was prepared by adding excess $\mathrm{FeCl}_{3}$ to an acid solution of sodium phytate. All media were adjusted to $\mathrm{pH} 6.3$ before autoclaving at $121^{\circ}$ for $\mathrm{I} 5 \mathrm{~min}$. There were eight separate experiments comparing treatments, and replication ranged from 12 to 24 tubes in each. Results from different experiments are not directly comparable because of seasonal differences in plant growth and infection, attributable to differences in light intensity.

Records. Ten to twelve weeks after inoculation, plants were tested for contamination and 
plant size and infection were recorded. Sterility was tested by adding some supernatant liquid from each tube to sterile nutrient broth (Oxoid), in which Endogone does not grow: broth with liquid from monoxenically infected, uncontaminated seedlings remained clear. The seedlings were then carefully removed from the melted agar, rinsed in warm water, dried between filter papers and weighed. Roots and attached external mycelium were stained by plunging into boiling lactophenol containing cotton blue $(0.0 \mathrm{I} \%, \mathrm{w} / \mathrm{v})$, leaving to simmer for ro min. and destaining in several changes of lactophenol. This treatment stained the fungus and cleared the tissue sufficiently for microscopic examination of whole, unsectioned roots.

Table I. Composition of media $(g . / l$.

\begin{tabular}{|c|c|c|c|}
\hline No. & & & mg. $\mathbf{P} / 1$. \\
\hline I & Io charcoal ${ }^{a}+0.2 \mathrm{CaCl}_{2}+\mathrm{FeEDTA}(7 \mathrm{mg}$. Fe $)$ & & 30 \\
\hline II & Io charcoal ${ }^{a}+0.2 \mathrm{CaCl}_{2}+$ FeEDTA $(7 \mathrm{mg}$. Fe $)$ & $+0.55 \mathrm{CaHPO}_{4} \cdot 2 \mathrm{H}_{2} \mathrm{O}$ & $100+30$ \\
\hline III & Io charcoal ${ }^{a}+0.2 \mathrm{CaCl}_{2}+$ FeEDTA $(7 \mathrm{mg}$. Fe) & $+\mathrm{I} \cdot 43 \mathrm{CaHPO}_{4} \cdot 2 \mathrm{H}_{2} \mathrm{O}$ & $260+30$ \\
\hline IV & Io charcoal ${ }^{a}+0.2 \mathrm{CaCl}_{2}+\mathrm{FeEDTA}(7 \mathrm{mg} . \mathrm{Fe})$ & $+0.63 \mathrm{Ca}$ phytate ${ }^{b}$ & $100+30$ \\
\hline V & Io charcoal ${ }^{a}+0.2 \mathrm{CaCl}_{2}+\mathrm{FeEDTA}(7 \mathrm{mg}$. Fe $)$ & $+0.63 \mathrm{Na}$ phytate ${ }^{c}$ & $100+30$ \\
\hline VI & Io charcoal ${ }^{a}+0.2 \mathrm{CaCl}_{2}+$ FeEDTA $(7 \mathrm{mg}$. Fe) & $+0.73 \mathrm{Fe}$ phytate & 100 approx. +30 \\
\hline VII & ro charcoal ${ }^{a}+0.2 \mathrm{CaCl}_{2}+\mathrm{FeEDTA}(7 \mathrm{mg} . \mathrm{Fe})$ & +0.73 phytin & 100 approx. +30 \\
\hline VIII & Io charcoal ${ }^{a}+0.2 \mathrm{CaCl}_{2}+\mathrm{FeEDTA}(7 \mathrm{mg} . \mathrm{Fe})$ & +0.76 DNA $^{c d}$ & 60 approx. +30 \\
\hline IX & Io charcoal ${ }^{a}+0.2 \mathrm{CaCl}_{2}+\mathrm{FeEDTA}(7 \mathrm{mg}$. Fe $)$ & + I.06 lecithin & 60 approx. +30 \\
\hline $\mathbf{X}$ & $0.2 \mathrm{CaCl}_{2}+\mathrm{FeEDTA}(7 \mathrm{mg} . \mathrm{Fe})$ & & 0 \\
\hline XI & $0.2 \mathrm{CaCl}_{2}+\mathrm{FeEDTA}(7 \mathrm{mg} . \mathrm{Fe})$ & $+0.55 \mathrm{CaHPO}_{4} \cdot 2 \mathrm{H}_{2} \mathrm{O}$ & 100 \\
\hline XII & $0.2 \mathrm{CaCl}_{2}+\mathrm{FeEDTA}(7 \mathrm{mg} . \mathrm{Fe})$ & $+1 \cdot 43 \mathrm{CaHPO}_{4} \cdot 2 \mathrm{H}_{2} \mathrm{O}$ & 260 \\
\hline XIII & $0.2 \mathrm{CaCl}_{2}+\mathrm{FeEDTA}(7 \mathrm{mg} . \mathrm{Fe})$ & $+0.63 \mathrm{Ca}$ phytate & 100 \\
\hline XIV & $0.2 \mathrm{CaCl}_{2}+\mathrm{FeEDTA}(7 \mathrm{mg}$. Fe) & +0.76 DNA & 60 approx. \\
\hline XV & $0.2 \mathrm{CaCl}_{2}+\mathrm{FeEDTA}(7 \mathrm{mg} . \mathrm{Fe})$ & $+\mathrm{I} \cdot 0$ glucose-6-phosphate & 100 \\
\hline XVI & $0 \cdot 2 \mathrm{CaCl}_{2}+\mathrm{FeEDTA}(7 \mathrm{mg} . \mathrm{Fe})$ & +0.12 inositole & 0 \\
\hline XVII & $0.2 \mathrm{NaCl}+\mathrm{FeCl}_{3}(3 \mathrm{mg} . \mathrm{Fe})$ & $+0.55 \mathrm{CaHPO}_{4} .2 \mathrm{H}_{2} \mathrm{O}$ & 100 \\
\hline XVIII & $0.2 \mathrm{CaCl}_{2}+\mathrm{FeCl}_{3}(35 \mathrm{mg} . \mathrm{Fe})$ & $+0.55 \mathrm{CaHPO}_{4} .2 \mathrm{H}_{2} \mathrm{O}$ & 100 \\
\hline XIX & $0.2 \mathrm{CaCl}_{2}+\mathrm{FeEDTA}$ (I mg. Fe) & $+0.55 \mathrm{CaHPO}_{4} \cdot 2 \mathrm{H}_{2} \mathrm{O}$ & 100 \\
\hline $\mathbf{X X}$ & $0.2 \mathrm{CaCl}_{2}+\mathrm{FeEDTA}$ (I mg. Fe) & $+0.63 \mathrm{Ca}$ phytate & 100 \\
\hline XXI & $0.2 \mathrm{CaCl}_{2}+\mathrm{FeCl}_{3}$ (I mg. $\mathrm{Fe}$ ) & $+0.55 \mathrm{CaHPO}_{4} .2 \mathrm{H}_{2} \mathrm{O}$ & 100 \\
\hline XXII & $0.2 \mathrm{CaCl}_{2}+\mathrm{FeCl}_{3}$ (I mg. Fe) & $+0.63 \mathrm{Ca}$ phytate & 100 \\
\hline
\end{tabular}

All media contained in addition $15 \mathrm{~g}$. Difco agar, $0.5 \mathrm{~g} . \mathrm{KNO}_{3}$ and $0.2 \mathrm{~g} . \mathrm{MgSO}_{4} .7 \mathrm{H}_{2} \mathrm{O}$.

${ }_{a}$ Total $\mathrm{P}$ content $0.3 \%(\mathrm{w} / \mathrm{w})$.

b Koch-Light Ltd, Colnbrook, Buckinghamshire. e Amount of inositol in $0.63 \mathrm{~g}$. Ca phytate.

c British Drug Houses Ltd, Poole, Dorset.

Presence or absence of VA infection was recorded and the most heavily infected part of the root system, usually the top quarter, was used for more detailed observations on the spread of infection, vesicle production in the root, the amount of external mycelium and numbers of extra-matrical spores. The complete root system was laid out in a Petri dish and $\mathrm{I} \cdot 5 \mathrm{~cm}$. was cut from within the most heavily infected part. The segments were placed on a microscope slide and individual roots were eased apart and covered with a coverslip. With the aid of an eye-piece graticule with crossed wires, three traverses were made across the root segments (at both ends and in the middle of the coverslip). Root infection was recorded in three categories; without infection (rating o), roots with about one-third of the cortex infected (rating I), and those with about two-thirds of the cortex infected (rating 2). The total infection rating was then expressed per 100 roots traversed giving a maximum rating of 200 (all roots with about two-thirds of the cortex infected). Roots with vesicles and the number of external spores met in the traverse were recorded separately. The numbers of external hyphae traversed were recorded as single hyphae or, when in strands, as two 
sizes containing approximately 25 (rating 25 ) or approximately 50 (rating 50 ) individual hyphae. These ratings were added to the number of single hyphae recorded. Four separate criteria of infection were therefore measured: (i) the intensity of VA infection in the root; (ii) the number of roots with vesicles; (iii) the estimated number of external hyphae; (iv) the number of extra-matrical (external) spores. In one experiment the total length of infected root system was measured.

\section{RESULTS}

\section{Effects of different sources and amounts of $P$ on the incidence and intensity of infection.}

Ungerminated Endogone spores produced typical VA infections in plants grown on a basic medium containing $\mathrm{N}$ and up to $100 \mathrm{mg}$. P/l. (Table 2). All the media contained

Table 2. Effects of different phosphate sources on the incidence of infection by Endogone sp.

\begin{tabular}{|c|c|c|c|c|c|}
\hline Medium & $\begin{array}{c}\text { Main } \\
\text { phosphate } \\
\text { source }\end{array}$ & $\begin{array}{l}\text { No. of plants } \\
\text { examined }\end{array}$ & $\begin{array}{l}\text { No. of plants } \\
\text { without } \\
\text { contamination }\end{array}$ & $\begin{array}{l}\text { No. of plants } \\
\text { with VA } \\
\text { infection }\end{array}$ & $\begin{array}{c}\text { No. of } \\
\text { VA } \\
\text { plants } \\
\text { without } \\
\text { contamination }\end{array}$ \\
\hline I & * None & $2 \mathrm{I}$ & I4 & 8 & 6 \\
\hline II & $\mathrm{CaHPO}_{4}$ & 23 & 16 & 5 & 4 \\
\hline IV & Ca phytate & 18 & 13 & 13 & 8 \\
\hline V & $\mathrm{Na}$ phytate & 24 & 15 & 6 & 2 \\
\hline VI & Fe phytate & 24 & 20 & 9 & 7 \\
\hline VII & Phytin & 24 & 15 & 3 & 3 \\
\hline VIII & DNA & 24 & 15 & 6 & 3 \\
\hline IX & Lecithin & 22 & I 8 & 5 & 5 \\
\hline
\end{tabular}

charcoal which supplied an extra $30 \mathrm{mg}$. P/l. Although some infected seedlings were also contaminated with other micro-organisms, mostly bacteria, there was no indication that contamination assisted VA infection. Although most plants became infected in the medium containing Ca phytate, many also became infected in media containing inorganic phosphate $\left(\mathrm{CaHPO}_{4}\right)$ or no phosphate. Infection did not therefore depend on any particular form of phosphate. However, it was sensitive to different concentrations (Table 3). In media with two levels of inorganic phosphate and no charcoal (X, XI, XII), the optimum P concentration for both incidence and intensity of infection was $100 \mathrm{mg} / \mathrm{l}$; with $260 \mathrm{mg}$./1. both plant growth and infection were less. In media containing charcoal (I, II, III), intensity of infection was greatest in medium I (30 mg. P/1.), less in II (I30 mg. P/1.) and least in III (290 mg. P/1.). The incidence of infection was also least in medium III although the higher $P$ level did not affect spore germination.

There was a significant interaction between charcoal and phosphate. Charcoal improved infection only when it was the sole source of $P$ (cf. media $X$ and I). It diminished the intensity of infection (though not its incidence) when 100 and $260 \mathrm{mg}$. P/l. were present as $\mathrm{CaHPO}_{4}$, probably by increasing the total $\mathrm{P}$ above the optimum. With $290 \mathrm{mg}$. P/l. (medium III), infection was no better than without $\mathrm{P}$ (medium $\mathrm{X}$ ), although plants were much larger. The optimum P concentration for VA mycorrhiza seemed to be between 30 and $100 \mathrm{mg} . / \mathrm{l}$.

Fungal growth outside the root, as measured by external mycelium and spores, was greater with the two organic forms of phosphate (Ca phytate and DNA) than with the inorganic. DNA in particular greatly stimulated the number of external spores (medium XIV, Fig. $2 a)$ and they were also significantly larger $(P<0.0 \mathrm{I})$ with a mean diameter of 
$25 \cdot 3 \mu \mathrm{m}$. compared with $22 \cdot 5 \mu \mathrm{m}$. with Ca phytate (medium XIII) and $2 \mathrm{I} \cdot 6 \mu \mathrm{m}$. with $\mathrm{CaHPO}_{4}$ (medium XI). Adding charcoal markedly reduced numbers of external spores in the DNA medium.

Table 3. Development of $V A$ infection and of external mycelium in media containing different amounts and sources of $P$.

Mean of 6 replicates.

\begin{tabular}{|c|c|c|c|c|c|c|c|c|}
\hline Medium & $\begin{array}{c}\text { Source of } \\
\mathbf{P}\end{array}$ & mg. $P / 1$. & $\begin{array}{l}\text { Fresh } \\
\text { wt (g.) }\end{array}$ & $\begin{array}{l}\text { Plants } \\
\text { infected* } \\
(\%)\end{array}$ & $\begin{array}{c}\text { Intensity } \\
\text { of } \\
\text { infection } †\end{array}$ & $\begin{array}{l}\text { Roots } \\
\text { with } \\
\text { vesicles } \dagger\end{array}$ & $\begin{array}{c}\text { External } \\
\text { mycelium }{ }^{\dagger}\end{array}$ & $\begin{array}{l}\text { External } \\
\text { spores } \dagger\end{array}$ \\
\hline \multicolumn{9}{|c|}{ No charcoal } \\
\hline $\mathrm{X}$ & None & 0 & 0.06 & 55 & 30 & 0.2 & 43 & 5 \\
\hline XI & $\mathrm{CaHPO}_{4}$ & 100 & 0.23 & 100 & 86 & 10 & 152 & 62 \\
\hline XII & $\mathrm{CaHPO}_{4}$ & 260 & 0.16 & 60 & 44 & 6 & 102 & 48 \\
\hline XIII & Ca phytate & 100 & 0.30 & 100 & 110 & 28 & 298 & 55 \\
\hline XIV & DNA & 60 & 0.24 & 86 & 93 & 6 & 304 & 138 \\
\hline \multicolumn{9}{|c|}{ With charcoal } \\
\hline I & charcoal & 30 & 0.11 & 100 & 55 & 3 & 115 & 15 \\
\hline II & $\begin{array}{c}\mathrm{CaHPO}_{4} \\
\text { charcoal }\end{array}$ & $\begin{array}{r}100 \\
30\end{array}$ & 0.30 & 100 & 30 & 3 & 44 & I0 \\
\hline III & $\begin{array}{c}\mathrm{CaHPO}_{4} \\
\text { charcoal }\end{array}$ & $\begin{array}{r}260 \\
30\end{array}$ & 0.29 & 70 & 16 & 0.3 & 34 & 5 \\
\hline IV & $\begin{array}{l}\text { Ca phytate } \\
\text { charcoal }\end{array}$ & $\begin{array}{r}100 \\
30\end{array}$ & 0.31 & 100 & 147 & $3 \mathrm{I}$ & 448 & 61 \\
\hline VIII & $\begin{array}{l}\text { DNA } \\
\text { charcoal }\end{array}$ & $\begin{array}{l}60 \\
30\end{array}$ & 0.21 & 94 & III & 6 & 214 & 23 \\
\hline
\end{tabular}

Standard errors: Intensity of infection \pm II Roots with vesicles $\pm I \cdot 8$. External mycelium \pm 3 8. External spores \pm 13 .

As there was a significant interaction between charcoal and phosphate treatments, and as the range of variation within treatments differed considerably, the standard errors should be regarded as approximations only. More reliable analyses using logarithmic transformations were also done.

* \% plants infected refers to Io or more plants/treatment. In all treatments there were some contaminated replicates which are included in these figures as there was no indication that contamination had affected either the incidence or character of the VA infection.

$\dagger$ For assessment methods, see text.

\section{Comparison of Ca phytate, inositol and glucose-6-phosphate}

Seedlings in medium XV with glucose-6-phosphate were not appreciably larger than those in medium XVI, which contained no added phosphate (Table 4). Apparently neither the plant nor the fungus used $P$ supplied as glucose-6-phosphate. Only half the seedlings became infected in this medium, and the intensity of infection was less than with either inositol or $\mathrm{Ca}$ phytate. In other experiments, in which glucose-6-phosphate was sterilized by filtration, plants grew very well but incidence $(50 \%)$ and intensity of infection were again much less than in comparable plants given $\mathrm{Ca}$ phytate. Spore germination was also less. This result agrees with an earlier observation (Mosse, 1959) that glucose depresses growth of the germ tubes of the fungus.

The effects of inositol (medium XVI) were very striking. Not only was the infection nearly as well developed as in medium XIII containing phytate, but the fungus was also distributed much more evenly through the medium, including the bottom half of the tube. This was reflected in the significantly greater infection of roots growing near the bottom of the tube in the inositol medium, in spite of the obvious phosphate starvation that kept the plants small and presumably also affected fungal growth. When $0.005 \mathrm{~g}$./1. was given, instead of 

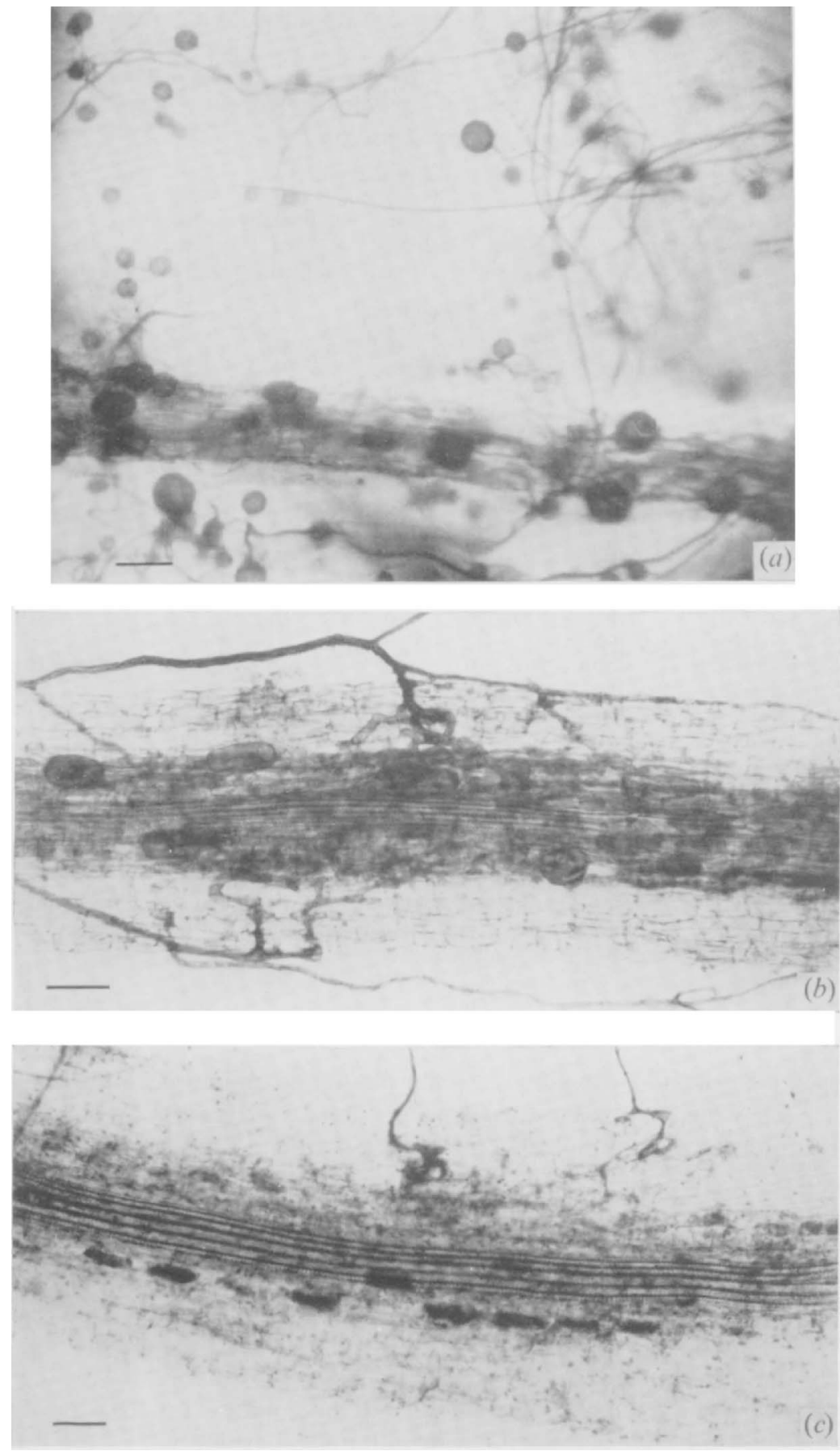

Fig. 2. (a) External mycelium and spores in medium XIV containing DNA; (b) Clover root with typical VA infection in medium XVIII containing $\mathrm{CaCl}_{2} ;(c)$ Clover root with typical VA infection in medium XVII containing $\mathrm{NaCl}$. Scales represent $100 \mu \mathrm{m}$. 


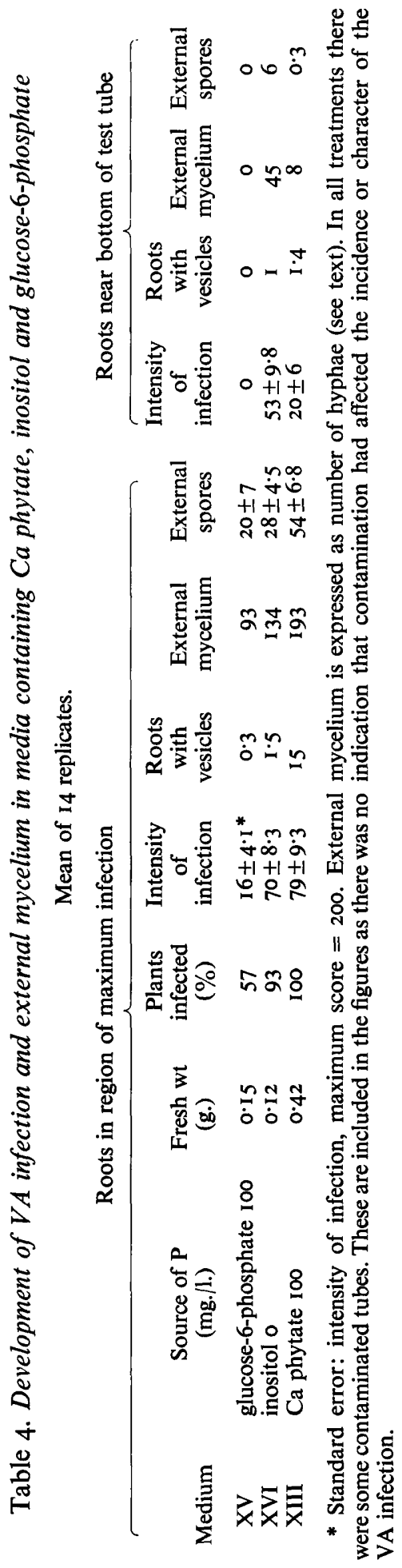


$0.12 \mathrm{~g} . / 1$. as in medium XVI, the intensity of infection was halved, showing that the response to inositol was to some extent dependent on concentration.

Some beneficial effects of $\mathrm{Ca}$ phytate noted earlier may therefore have been due to its inositol component, which could have acted as a carbon source for the fungus. In the purely inorganic medium the only carbon sources available to the fungus would have come either from the plant or, less probably, from atmospheric $\mathrm{CO}_{2}$.

To investigate the relationship between fungal development inside and outside the root, correlations were calculated between intensity of infection and external mycelium. In media containing $\mathrm{CaHPO}_{4}$ the correlation coefficient was $0.85 \pm 0.05$, and for media containing Ca phytate it was $0.86 \pm 0.05$, but for media with inositol it was $0.40 \pm 0.15$. Thus, with Ca phytate or $\mathrm{CaHPO}_{4}$, the external development of the fungus was closely related to its spread within the root, whereas with inositol it was less dependent on internal infection, again suggesting that inositol may act as an alternative carbon source.

\section{Comparison of $\mathrm{Fe}-\mathrm{EDTA}$ and $\mathrm{FeCl}_{3}$}

When, as in Jensen's medium, $\mathrm{FeCl}_{3}(0 . \mathrm{I}$ g./l.) was given (medium XVIII) all plants became infected. Therefore Fe-EDTA had no specific effect on VA infection. However, when very small amounts of $\mathrm{Fe}-\mathrm{EDTA}$ and $\mathrm{FeCl}_{3}$ were supplied (I mg. Fe/l., Table 5) the Fe-EDTA was insufficient for normal growth, and infection was also decreased to $30 \%$ when $\mathrm{CaHPO}_{4}$ was the phosphate source (medium XIX). Analysis of the Ca phytate showed it to contain a small amount of iron as impurity (less than $5 \mu \mathrm{g} . / \mathrm{g}$.), and this was enough to give normal growth and $100 \%$ infection (medium XX).

Table 5. Effects of low levels of $\mathrm{Fe}-\mathrm{EDTA}$ and $\mathrm{FeCl}_{3}$ on the incidence of $V A$ infection in, and growth of Trifolium parviflorum

\begin{tabular}{|c|c|c|c|c|}
\hline Medium & $\begin{array}{l}\text { Iron source } \\
(1 \mathrm{mg} . \mathrm{Fe} / \mathrm{l} .)\end{array}$ & P source & $\begin{array}{c}\text { Mean fresh } \\
\text { wt (g.) }\end{array}$ & $\begin{array}{c}\text { Plants infected } \\
(\%)\end{array}$ \\
\hline XIX & Fe-EDTA & $\mathrm{CaHPO}_{4}$ & 0.13 & 30 \\
\hline$X X$ & Fe-EDTA & Ca-phytate & 0.42 & 100 \\
\hline XXI & $\mathrm{FeCl}_{3}$ & $\mathrm{CaHPO}_{4}$ & 0.34 & 100 \\
\hline XXII & $\mathrm{FeCl}_{3}$ & Ca-phytate & 0.36 & 100 \\
\hline
\end{tabular}

\section{Effect of sodium}

In two experiments, sodium, present in the medium either as $\mathrm{NaCl}(80 \mathrm{mg} . \mathrm{Na} / \mathrm{l} .$, medium XVII), or as $\mathrm{Na}$ phytate (70 mg. $\mathrm{Na} / 1$., medium $\mathrm{V}$ ) affected the internal development of the fungus, restricted its longitudinal spread and often confined infection to a single layer of cells next to the endodermis. Fresh weight of plants, number of infections per plant and

\begin{tabular}{|c|c|c|c|c|}
\hline \multirow[b]{2}{*}{ Medium } & \multicolumn{3}{|c|}{ Mean of 14 replicates. } & \multirow[b]{2}{*}{$\begin{array}{l}\text { Total length } \\
\text { infected } \\
\text { tissue/plant } \\
\text { (cm.) }\end{array}$} \\
\hline & $\begin{array}{l}\text { Fresh wt } \\
\text { (g.) }\end{array}$ & $\begin{array}{c}\text { Plants infected } \\
(\%)\end{array}$ & $\begin{array}{l}\text { No. } \\
\text { infections/plant }\end{array}$ & \\
\hline XVII ( $\mathrm{NaCl})$ & 0.28 & 100 & 16 & 27 \\
\hline XVIII $\left(\mathrm{CaCl}_{2}\right)$ & 0.42 & roo & 40 & 63 \\
\hline
\end{tabular}

total length of infected tissue were significantly less in medium XVII containing $\mathrm{NaCl}$, than in medium XVIII with $\mathrm{CaCl}_{2}$ (Table 6). Instead of $78 \%$ of roots with two-thirds of the cortex infected, there were only $32 \%$ in the $\mathrm{NaCl}$ medium. Fig. 2, (b) and (c) show 
typical infections. Although the two media (XVII and XVIII) also contained different amounts of $\mathrm{Fe}, 3$ and $35 \mathrm{mg} . / 1$. respectively, it is improbable that this would have accounted for the result. Even I mg. Fe/l. given as $\mathrm{FeCl}_{3}$ (media XXI and XXII, Table 5) was sufficient for normal growth and infection. Infections were also sparser and more restricted with $\mathrm{Na}$ phytate than with $\mathrm{CaHPO}_{4}$ as a source of $\mathrm{P}$. The large sodium content of Jensen's medium may therefore have contributed to the difficulties of obtaining VA infections in it.

\section{DISCUSSION}

Clearly the synthesis of VA mycorrhiza in culture is much affected by amounts of phosphate in the medium. Optimum amounts of $\mathrm{CaHPO}_{4}$ were of the order of $100 \mathrm{mg}$. $\mathrm{P} / \mathrm{l}$. (medium XI, Table 3). The intensity but not the incidence of infection was diminished when an extra $30 \mathrm{mg}$. P was given in the form of charcoal (medium II, Table 3). More (260 mg./l.) reduced both incidence and intensity of infection (medium XII, Table 3) and additional charcoal still further decreased the intensity (medium III, Table 3). Although there were significant interactions with charcoal, there was no evidence that it was harmful provided $\mathbf{P}$ concentration did not exceed the optimum. Charcoal had originally been added as an adsorbent of possible toxic substances that might interfere with mycorrhizal development, but infection clearly did not depend on it (Table 3). It is concluded that the difficulties experienced in obtaining VA mycorrhiza in Jensen's medium were connected with its high $P$ content $\left(265 \mathrm{mg}\right.$./1.), especially as some of this $\mathrm{P}$ was in the form of $\mathrm{K}_{2} \mathrm{HPO}_{4}$ with a solubility of $167 \mathrm{~g}$./l. compared with $0.32 \mathrm{~g}$./1. for $\mathrm{CaHPO}_{4}$, equivalent to $60 \mathrm{mg}$. P/l. If, as is improbable, all the $P$ in $10 \mathrm{ml}$. of medium XI were absorbed into a plant of $40 \mathrm{mg}$. dry weight, the concentration of $P$ would reach $2.5 \%(\mathrm{w} / \mathrm{w})$ and with more than twice as much $\mathrm{P}$ it could exceed this because more phosphate dissolves and is gradually taken up. Greenwood \& Hallsworth (1960) and Asher \& Loneragan (1967) found a decrease in growth and other adverse effects of supra-optimal phosphate uptake in subterranean clover containing $\mathrm{I} \cdot 3 \% \mathrm{P}$. Therefore the phosphate concentrations in Jensen's medium may affect metabolic processes in the host plant that might alter its liability to infection. However, high $\mathbf{P}$ concentrations in the medium could also affect the fungus directly, although customary media for growing fungi often contain up to I g. $\mathrm{K}_{2} \mathrm{HPO}_{4} / \mathrm{l}$. equivalent to $228 \mathrm{mg}$. P/l. However Endogone may well be an unusual fungus.

It is known that in soil also high P levels decrease and finally eliminate mycorrhizal infection (Baylis, 1967; Mosse, 197I), and Daft \& Nicolson (1969) obtained decreasing infection with increasing additions of $\mathrm{KH}_{2} \mathrm{PO}_{4}$ in sand culture. How $\mathrm{N}$ starvation counteracts the effects of too much P is not understood, but both in Jensen's medium (Mosse, 1962) and in pot experiments with soil (Baylis, 1967; Mosse, 1967) this effect was observed. According to Cochrane (1958) lack of $\mathrm{N}$ in a fungal medium may be expected to act directly on $\mathrm{P}$ absorption by restricting the energy required for its uptake. On the other hand symptoms of $\mathbf{P}$ toxicity in plants can be reduced by adding N (Greenwood \& Hallsworth, 1960 ; Bhatti \& Loneragan, 1970).

The agreement between results with plants grown in soil and in agar culture is encouraging, because the latter offer considerable advantages for studying the physiology of mycorrhizal associations. The responses and development of the external (extra-matrical) mycelium can be more accurately assessed and the method described in this paper showed that Ca phytate, DNA and inositol greatly stimulated the external mycelium. Inositol in particular seemed to make hyphal growth in the agar independent of its spread in the root. Inositol can function as a growth factor for some micro-organisms but, since its effect was to some extent de- 
pendent on concentration it may well have acted as a carbon source. With inositol in the medium even small, phosphate-starved plants were heavily infected (medium XVI, Table 4) whereas generally, small and nutritionally deficient plants like those in media X (Table 3), XV (Table 4), XIX (Table 5) and XVII (Table 6), were only slightly or not at all infected. That inositol and phytates may be beneficial for independent growth of Endogone is interesting and possibly relevant to its ecological situation. In soils glucose, which does not appear to be utilized by Endogone, is present in small amounts and many micro-organisms compete for it. On the other hand phytates form the greater part of the organic phosphate fraction in soils (Anderson, 1956) and are clearly relatively resistant to microbial attack, so that Endogone might have a readily available carbon source in many soils.

We thank Miss G. A. Oakey for much painstaking technical help and for the diagram in Fig. $\mathbf{I}$.

\section{REFERENCES}

ANDERSON, G. (1956). Identification and estimation of soil inositol phosphates. Journal of the Science of Food \& Agriculture 7, 437-44.

ASHER, C. J. \& LONERAGAN, J. F. (1967). Response of plants to phosphate concentration in solution culture. I. Growth and phosphorus content. Soil Science I03, 225-33.

BAYLIs, G. T. S. (1967). Experiments on the ecological significance of phycomycetous mycorrhizas. New Phytologist 66, 23I-43.

Bhatti, A. S. \& Loneragan, J. F. (1970). The effect of early superphosphate toxicity on the subsequent growth of wheat. Australian Journal of Agricultural Research 21, 88I-92.

ClaRK, G. (1914). Phytin and phytic acid. Journal of the Chemical Society 105, 535-45.

Cochrane, V. W. (1958). Physiology of fungi. New York: John Wiley.

DAFT, M. J. \& Nicolson, T. H. (1969). Effect of Endogone mycorrhiza on plant growth. II. Influence of soluble phosphate on endophyte and host in maize. New Phytologist 68, 945-52.

Greenwood, E. A. N. \& Hallsworth, E. G. (I960). Studies on the nutrition of forage legumes. II. Some interactions of calcium, phosphorus, copper and molybdenum on the growth and chemical composition of Trifolium subterraneum L. Plant and Soil 12, 97-127.

JeNSEN, H. L. (1942). Nitrogen fixation in leguminous plants. II. Is symbiotic nitrogen fixation influenced by Azotobacter? Proceedings of the Linnean Society of N.S.W. 67, 205-12.

Mosse, B. (1959). The regular germination of resting spores and some observations on the growth requirements of an Endogone sp. causing vesicular-arbuscular mycorrhiza. Transactions of the British Mycological Society 42, 273-86.

Mosse, B. (1962). The establishment of vesicular-arbuscular mycorrhiza under aseptic conditions. Journal of General Microbiology 27, 509-20.

Mosse, B. (1967). Annual Report Rothamsted Experimental Station for 1966, p. 88.

Mosse, B. (197I). Annual Report Rothamsted Experimental Station for 1970, p. 89.

Nicolson, T. H. \& GerdemanN, J. W. (1968). Mycorrhizal Endogone species. Mycologia 6o, 313-25.

NutMAN, P. S. (1949). Nuclear and cytoplasmic inheritance of resistance to infection by nodule bacteria in red clover. Heredity 3, 263-9I. 